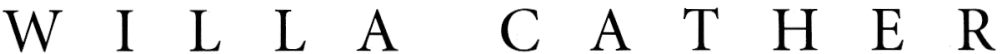

S C H O L A R L Y E D I T I O N

\section{My Ántonia}

Edited by Charles Mignon with Kari Ronning

Historical essay and explanatory notes by James Woodress

Illustrations by W.T. Benda

Cather called My Ántonia, "the best thing I've done." This novel, hailed by reviewer after reviewer for its originality, vitality, and truth, secured

Cather's place in the first rank of American writers.......... Mencken

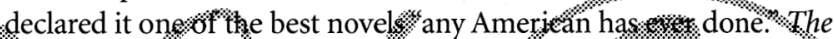

Nation plisiced it "smong the\%est of our/recentinterpsetations of

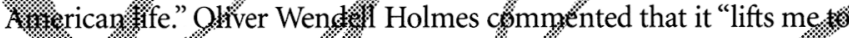

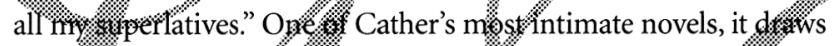

2. deepl/y or ter childhood experiences.

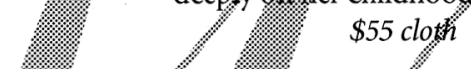

\section{O Pioneers!}

Edited b. Susth J. Rosowski and Châri.s Migion with Kathleen Danker

Histrical Introduction and Explanatory Nơtes by David Stouck

Willa Cather said of O Pioneers! that it was her first authentic novel,

"the first time I walked off on my own feet - everything before was half real and half an imitation of writers whom I admired."

Published in 1913, Cather's novel of life on the Nebraska frontier received enthusiastic reviews. Besides establishing her career as a writer of great note, $O$ Pioneers! marked a significant turning point in Cather's artistic development: no longer would she let literary convention guide the form of her writing; the materials themselves would dictate the structure. The critical and popular success of $O$ Pioneers! encouraged Cather to follow the same road with subsequent novels.

\section{$\$ 45$ cloth}

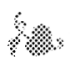

The volumes in the Willa Cather Scholarly Edition place Cather's novels

in historical context as well as provide definitive critical texts. A historical introduction situates each novel in its own time and in the context of Cather's career. Explanatory notes and illustrations clarify the allusions that may be unfamiliar to present-day readers and tie the text to scenes and details from Cather's actual experience. 


\section{The Real Thing}
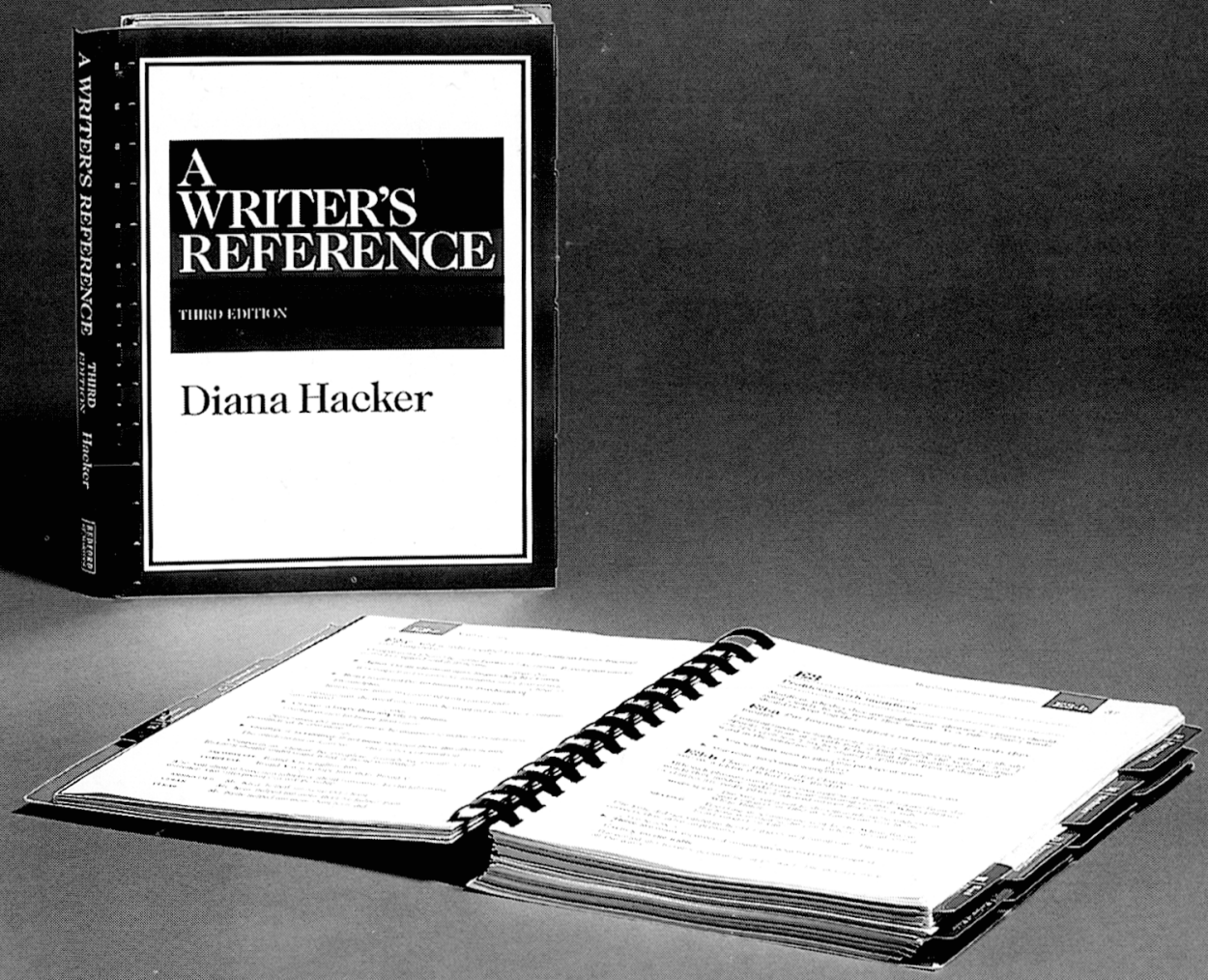

Available in fanuary

\section{Bedford Books of St. Martin's Press For exam copies, call 1-800-446-8923}

